\title{
PLANNING DEVELOPMENT OF TOURISM IN TUZLA CANTON AS A FACTOR OF REGIONAL DEVELOPMENT OF NORTHEAST BOSNIA
}

\begin{abstract}
Senada Nezirović ${ }^{1}$
Abstract: Tuzla Canton is located in the northeastern part of Bosnia and Herzegovina and is one of the ten administrative and political organizations of the Federation of Bosnia and Herzegovina. In this work, the area of Tuzla Canton is seen as a destination with an attractive, functional, material and organizational elements. During this process, natural and other cultural tourism values that were partially used in the development of tourism were observed and analyzed. For recognition and identification of the key factors of development and the restrictions of individual tourist destinations SWOT analysis was used, on which basis some priorities, measures, development vision and projects that will contribute to the development of tourism in Tuzla Canton were formulated. On the basis of the results of assessing the situation and development possibilities of Tuzla Canton we can convert comparative advantages into competitive advantages and external threats into development opportunities. After assessing the overall tourism potential, factors that affect the larger economic effects are separated, guidance is given on the development of tourism infrastructure and the optimal use of tourism potential, all the while connecting the narrower destinations and creating the position of Tuzla Canton as a significant tourist destination in the region of northeastern Bosnia.
\end{abstract}

Key words: Tuzla Canton, planned development, factors of tourist offer, tourism, northeast Bosnia

\section{INTRODUCTION}

Tourism industry is a significant driver of economic development in the world, as an activity it connects different peoples and cultures, and is becoming a more modern activity dealt by a man. Economic effects on economic activities agriculture, transport, trade, health care, construction and trades are achieved by development of tourism. Bosnia and Herzegovina has considerable tourist resources, thus opening the possibility of entering the tourism market. It is a known fact that Bosnia and Herzegovina economy suffered significant material and human losses during the last war, which unfortunately still reflect on further development. More efficient access to the tourist market requires a new approach in the use of basic instruments of business and tourism policy, a renewal and improvement of the position that Bosnia and Herzegovina can and should have in these relations. In Tuzla canton, there is a remarkable increase in tourist activity, which was the immediate cause for the analysis of available natural and cultural tourism values and their planned use in the development of the tourism industry. After the last war in Bosnia and Herzegovina that took place from 1992 to 1995, the territory of Bosnia and Herzegovina is administratively regulated as a complex state with two entities and one district. Bosnia and Herzegovina is consisted of the Federation of Bosnia and Herzegovina, Republic of Srpska and the Brčko District.

\footnotetext{
${ }^{1}$ PhD Senada Nezirović, Assistant Professor, Department of Geography, Faculty of Science, University of Sarajevo, Sarajevo, Bosnia and Hercegovina.
} 


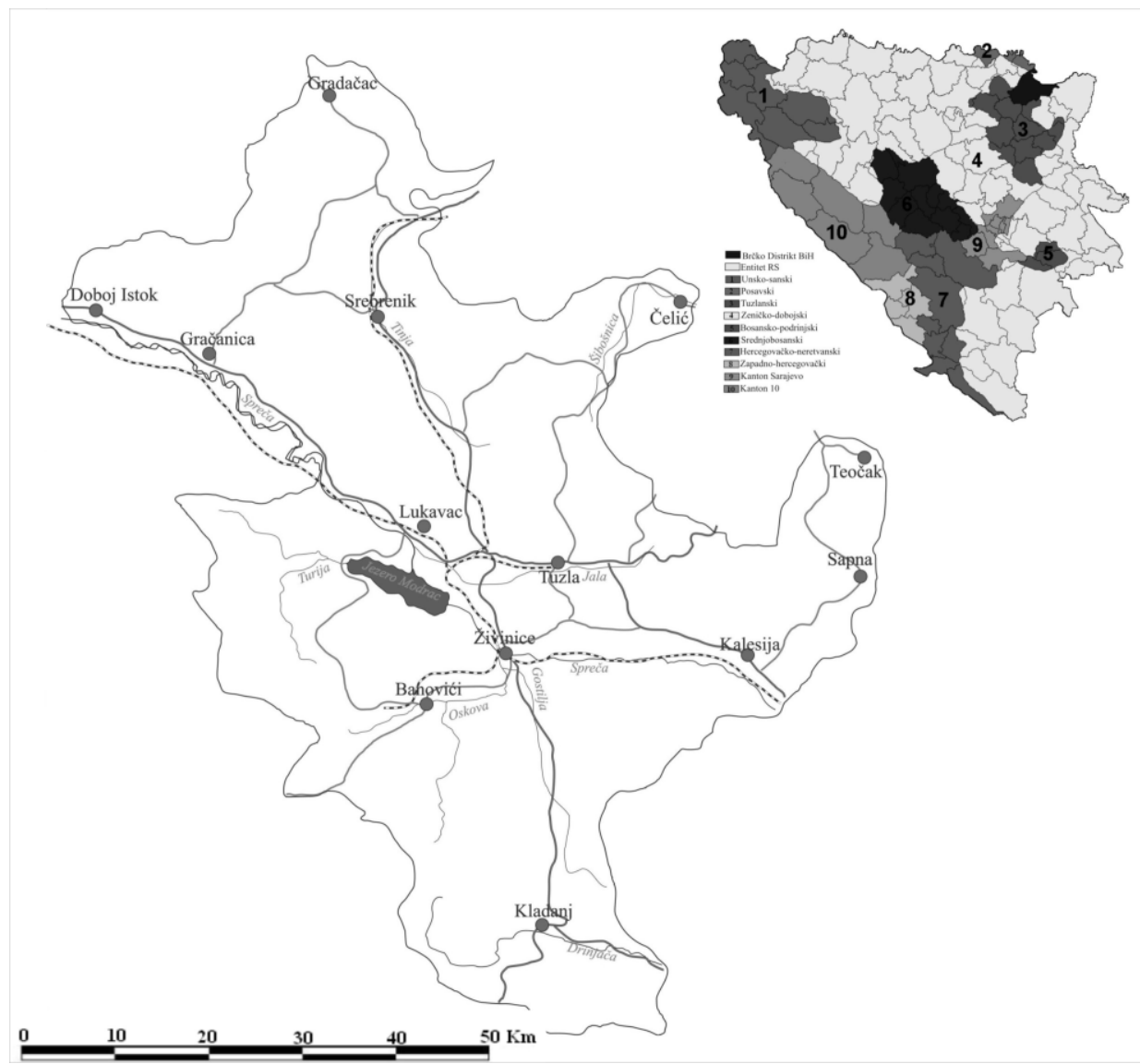

Fig 1. Geotraffic location of Tuzla Canton

(the map done by the author)

The entities and Brčko District don't have state sovereignty, and the boundaries between them don't have the characteristics of the state border. The territory of the Federation of Bosnia and Herzegovina is regulated at the cantonal principle, under which there are ten cantons. Cantons are administrative and political communities, which bring together municipalities, as the lowest form of administrative organization of government in its territory. As part of the Tuzla Canton there are 13 municipalities and these are: Banovići, Doboj-Istok, Gračanica, Gradačac, Kladanj, Kalesija, Čelic, Lukavac, Srebrenik, Sapna, Teočak, Tuzla and Živinice. The main administrative, cultural, commercial and economic center of the Canton is the city of Tuzla. From regional-geographical aspect, the Tuzla Canton belongs to northeastern part of the macro-region of Northern Bosnia. The territory of Tuzla Canton has a surface of 2.652 square kilometers with the population of 477.278 inhabitants. The area is traffically connected to all parts of the country. The main road is the Županja-Tuzla-Sarajevo-Mostar,in addition to exiting to the international E-70 corridor Zagreb-Belgrade, it connects parts of the Pannonian and continental region with the Adriatic sea. In the last decade of the twentieth century (1998), air transport was established by the Tuzla International Airport. Furthermore, in the paper, there is given a short analysis of the areas where there are tourism resources and facilities with predominant function of tourism, or in which tourism can become a significant economic activity. 


\section{EVALUATION OF PREVIOUS DEVELOPMENT OF TOURISM IN THE TUZLA CANTON}

For the modern tourism development and attracting visitors to tourist destinations that are suitable for rest, recreation and treatment, special attention goes to tourism planning, support from the current government and connection among tourism associations. Local communities in the area of Tuzla Canton have recognized the opportunity in the development of tourism by continuing started activities in the development of tourism infrastructure, which is of a great importance for the tourist offer in the future. Capacities of tourist accommodation are the basis of tourist traffic, be it hotel accommodation or camping. In the area of Tuzla Canton, accommodation is offered by 52 facilities possessing 787 rooms with 1.419 beds.

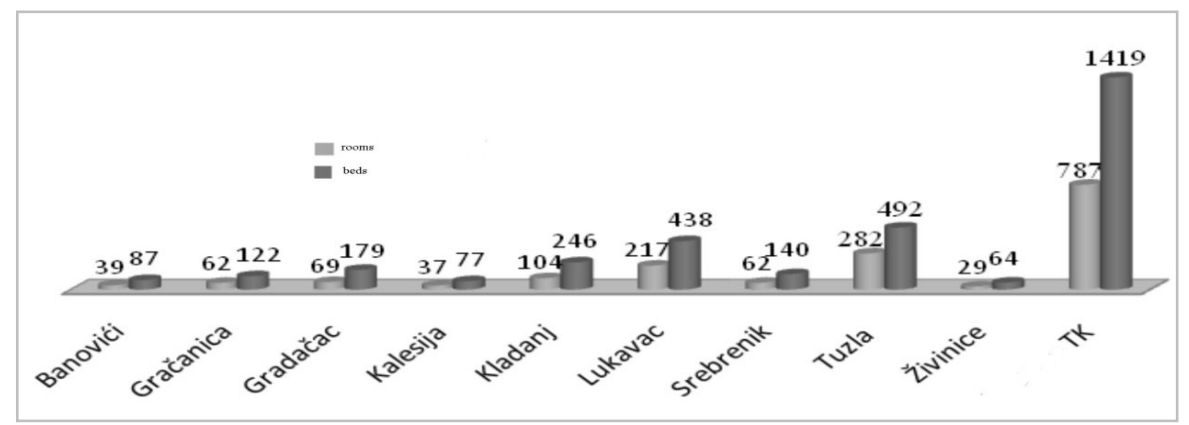

Fig 2. Structure of accommodation capacities in the area of Tuzla Canton

For assessing the success of the tourism industry, the Ministry of Trade, Tourism and Transport monitors the arrival and movement of visitors in the area of Tuzla Canton. These activities are conducted through regular monthly reports of business entities that provide accommodation services. According to the indicators listed, in the accommodation facilities in the area of Tuzla Canton for the period 2009/2013, there were 151.783 visitors who accounted for 421.667 overnight stays.

Tab. 1. Tourism in the accommodation capacities TK for the period 2009-2013

\begin{tabular}{|l|l|l|l|l|l|l|}
\hline & \multicolumn{3}{|c|}{ Arrivals } & \multicolumn{3}{c|}{ Nights } \\
\hline Year & Domestic & Foreign & Total & Domestic & Foreign & Total \\
\hline 2009 & 20.809 & 13.873 & 34.682 & 64.996 & 30.516 & 95.512 \\
\hline 2010 & 21.435 & 12.432 & 33.867 & 64.559 & 24.160 & 88.719 \\
\hline 2011 & 15.320 & 11.227 & 26.547 & 56.725 & 22.420 & 79.145 \\
\hline 2012 & 14.979 & 10.495 & 25.474 & 54.172 & 18.832 & 73.004 \\
\hline 2013 & 20.274 & 10.939 & 31.213 & 63.317 & 21.970 & 85.287 \\
\hline $2009-2013$ & 92.817 & 58.996 & $\mathbf{1 5 1 . 7 8 3}$ & 303.769 & 117.898 & $\mathbf{4 2 1 . 6 6 7}$ \\
\hline
\end{tabular}

Source: The Government of Tuzla Canton, The Ministry of Trade, Tourism and Transport of Tuzla Canton,Tuzla,2014.

In 2013 , there were 31.213 visitors or $5,4 \%$ of total arrivals to the Federation of $\mathrm{BiH}(577$. 077 ), or $3,7 \%$ to the territory of Bosnia and Herzegovina (844.189). 
Tab. 2. Comparative indicators of the arrival of visitors to the territory of Bosnia and Herzegovina in 2013.

\begin{tabular}{|l|l|l|l|l|l|}
\hline Visitors & $\mathrm{BiH}$ & $\mathrm{FBiH}$ & $\mathrm{TK}$ & \% in $\mathrm{FBiH}$ & \% in FBiH \\
\hline $\begin{array}{l}\text { Domesti } \\
\mathrm{c}\end{array}$ & 315.61 & $\begin{array}{l}166.42 \\
7\end{array}$ & 20.274 & 12,2 & 6,4 \\
\hline Foreign & $\begin{array}{l}528.57 \\
9\end{array}$ & $\begin{array}{l}410.65 \\
0\end{array}$ & 10.939 & 2,6 & 2,1 \\
\hline Total & 844.18 & 577.07 & $\mathbf{3 1 . 2 1 3}$ & 5,4 & 3,7 \\
& 9 & 7 & & & \\
\hline
\end{tabular}

Source: The Government of Tuzla Canton, The Ministry of Trade, Tourism and Transport of Tuzla Canton, Tuzla,2014.

According to the total number of overnight stays, the leading are the local communities of municipalities of Gradačac, which thanks to a spa health resort achieved 55\%, Tuzla 19\%, and Lukavac 13\%. The most numerous visitors are from Serbia, Croatia, Slovenia, Germany, Austria, Italy and Turkey. According to the number of overnight stays in the Tuzla Canton, it is evident that foreign visitors made 1-2 overnight stays and it can be concluded that these were visits of business character. In these tourist facilities, visitors achieved the revenue of 23.648.657 KM. In accordance with the type of catering facilities, hotels have the main share of 8.351.121 KM, restaurants of 9.256.367 KM, canteens and serving facilities of 2.638.383 KM, and other catering facilities.

Tab. 3. Tourism in Tuzla Canton for the period 2009-2013

\begin{tabular}{|l|r|r|r|r|r|}
\hline Type of facilities & \multicolumn{1}{|l|}{2009} & 2010 & 2011 & 2012 & 2013 \\
\hline Hotels & 10.28378 & 9.281 .30 & 8.228 .99 & 8.453 .25 & 8.351 .121 \\
& 1 & 3 & 2 & 8 & \\
\hline Restaurants & 6.947 .862 & 7.562 .20 & 8.199 .04 & 9.019 .25 & 9.256 .367 \\
& & 2 & 5 & 2 & \\
\hline Taverns & 978.287 & 979.142 & 1.068 .23 & 500.803 & 386.695 \\
& & & 2 & & \\
\hline Bars & 146.978 & 112.263 & 111.340 & 306.235 & 400.827 \\
\hline $\begin{array}{l}\text { Camping sites and } \\
\text { other }\end{array}$ & 160.020 & 164.109 & 159.814 & 104.441 & 132.203 \\
\hline Buffet & 344.338 & 330.295 & 411.746 & 374.362 & 1.711 .613 \\
\hline Serving facilities & 6.060 .386 & $6.075 . .87$ & 6.689 .82 & 4.890 .30 & 2.638 .383 \\
& & 7 & 5 & 6 & \\
\hline Total & 24.921 .6 & 24.505 .1 & 24.868 .9 & 22.877 .2 & 23.648 .65 \\
& 52 & 91 & 94 & 09 & 7 \\
\hline
\end{tabular}

Source: The Government of Tuzla Canton, The Ministry of Trade, Tourism and Transport of Tuzla Canton, Tuzla, 2014.

According to types of catering services provided in tourist catering facilities in the area of Tuzla Canton, the highest demand are services of food, drink and accommodation, followed by other services of visible and invisible trade. The highest turnover was recorded through foodservice that is positive for the cooperation of the tourist industry and agriculture through the placement of the domestic agricultural products. Overnight stays 
reached the revenue of 3.208.643 KM, which shows a slight decrease, considering that there was a smaller number of overnight stays compared to the previous periods.

Tab. 4. Tourist traffic by type of service in Tuzla Canton for the period 2009-2013

\begin{tabular}{|l|r|r|r|r|r|}
\hline Type of services & 2009 & 2010 & 2011 & 2012 & 2013 \\
\hline Beer & 859.552 & 1.039 .91 & 1.067 .92 & 1.007 .38 & 1.267 .70 \\
& & 3 & 3 & 0 & 5 \\
\hline Wine & 928.193 & 997.893 & 943.566 & 968.862 & 930.660 \\
\hline Brandy & 145.566 & 127.084 & 95.078 & 92.110 & 103.460 \\
\hline Other alcohol drinks & 392.835 & 465.955 & 399.936 & 346.803 & 291.425 \\
\hline Fruit juices & 670.726 & 847.307 & 993.930 & 810.275 & 763.012 \\
\hline $\begin{array}{l}\text { Other non alcoholic } \\
\text { drinks }\end{array}$ & 1.177 .346 & 1.195 .29 & 1.363 .12 & 1.683 .10 & 1.700 .11 \\
\hline $\begin{array}{l}\text { Mineral water and } \\
\text { soda }\end{array}$ & 657.365 & 718.131 & 760.694 & 657.623 & 616.581 \\
\hline Food & & & & & 9 \\
& 14.291 .83 & 13.819 .1 & 14.483 .7 & 12.867 .2 & 11.529 .7 \\
\hline Beverages & 8 & 37 & 68 & 61 & 67 \\
\hline Tobacco and matches & 3.780 .001 & 1.519 .76 & 1.233 .82 & 1.192 .53 & 1.526 .66 \\
\hline Other goods turnover & 18.550 & 50.879 & 51.963 & 53.992 & 65.812 \\
\hline $\begin{array}{l}\text { Other non goods } \\
\text { turnover }\end{array}$ & 190.253 & 119.755 & 30.223 & 19.559 & 6.717 \\
\hline Nights & & & 54.253 & 942.079 & 866.644 \\
& 3.771 .489 & 3.587 .48 & 3.390 .71 & 3.007 .06 & 3.208 .64 \\
\hline Total & $\mathbf{2 4 . 9 2 1 . 6}$ & $\mathbf{2 4 . 5 0 5 . 1}$ & $\mathbf{2 4 . 8 6 8 . 9}$ & $\mathbf{2 2 . 8 7 7 . 2}$ & $\mathbf{2 3 . 6 4 8 . 6}$ \\
& $\mathbf{5 2}$ & $\mathbf{9 1}$ & $\mathbf{9 4}$ & $\mathbf{0 9}$ & $\mathbf{5 1}$ \\
\hline
\end{tabular}

Source: The Government of Tuzla Canton,The Ministry of Trade, Tourism and Transport of Tuzla Canton, Tuzla, 2014.

By analyzing the actual effects of tourist spending in tourist catering facilities, it is noted that receptive factors of tourist offer lack effects which tourism should leave in the development of the overall economy. This primarily applies to catering facilities in which dominate the classic forms of taverns, cafes, buffets and aščinice (restaurants serving traditional stews and pies) with a lack of culinary specialties of local cuisine.

\section{Rating of tourism development in the Tuzla Canton by visitors}

During the 2014 summer season, I surveyed visitors in accommodation facilities in the Tuzla Canton. The survey was completed by six hundred respondents who gave a substantial contribution to this research by their replies. When filling out the questionnaire, the visitors had the opportunity to express their views and give their answers to posed questions on the possibilities of tourism development, and give evaluation of tourist sites in the area of Tuzla Canton. On this occasion, the visitors have pointed to special tourist values of the area and factors that are important in the overall tourist development of the area. 
Tab. 5. Rating of tourism development in Tuzla Canton by visitors

\begin{tabular}{|c|c|c|c|c|c|}
\hline \multirow{2}{*}{$\begin{array}{l}\text { Question } \\
\text { Do you think that the area of TK has } \\
\text { the conditions for tourism development }\end{array}$} & \multicolumn{4}{|c|}{ Answer } & \multirow[t]{2}{*}{$\begin{array}{c}\text { Tot } \\
\text { al }\end{array}$} \\
\hline & Yes & No & $\begin{array}{c}\text { I do } \\
\text { not } \\
\text { know }\end{array}$ & - & \\
\hline Replies & 450 & 50 & 100 & - & 600 \\
\hline$\%$ & $75 \%$ & $8 \%$ & $17 \%$ & & \\
\hline $\begin{array}{l}\text { In your opinion can tourism } \\
\text { development may affect the overall } \\
\text { economic development }\end{array}$ & Yes & No & & & \\
\hline Replies & 520 & 80 & - & - & 600 \\
\hline & $72 \%$ & $28 \%$ & & & \\
\hline $\begin{array}{l}\text { What are the most important factors in } \\
\text { the development of tourism TK }\end{array}$ & $\begin{array}{l}\text { accommoda } \\
\text { tion } \\
\text { facilities }\end{array}$ & $\begin{array}{c}\text { Roa } \\
\text { ds }\end{array}$ & $\begin{array}{l}\text { Food } \\
\text { and } \\
\text { drink }\end{array}$ & $\begin{array}{l}\text { Servic } \\
\text { es }\end{array}$ & \\
\hline Number of replies & 250 & 150 & 120 & 80 & $\begin{array}{c}60 \\
0\end{array}$ \\
\hline$\%$ & $42 \%$ & $25 \%$ & $20 \%$ & $13 \%$ & \\
\hline
\end{tabular}

The survey questionnaire provided the following results: $75 \%$ of respondents believe that the Tuzla Canton has conditions for tourism development, $72 \%$ believe that the development of tourism has an impact on the overall economic development, $42 \%$ think that the most important factor in the development of tourism is accommodation.

In the assessment of natural resources, $59 \%$ of respondents believe that these are Pannonian salt lakes, $16 \%$ healing springs, 12\% the protected landscape Konjuh, $8 \%$ artificial lakes, $5 \%$ the hunting grounds of Konjuh. In the assessment of cultural heritage, $42 \%$ of respondents believe that it is Etno avlija Banovići, 25\% kula Huseinbega Gradaščevića (the tower of Huseinbeg Gradaščević) in Gradačac, 20\% the Archaeological Park and the Neolithic settlement in Tuzla, 8\% medieval fortress Srebrenik, 5\% religious facilities.

Tab. 6. Rating tourist sites in Tuzla Canton by visitors

\begin{tabular}{|c|c|c|c|c|c|}
\hline \multicolumn{6}{|l|}{ Tourist sites } \\
\hline natural resources & $\begin{array}{l}\text { Number of } \\
\text { replies }\end{array}$ & $\%$ & $\begin{array}{l}\text { Objects of cultural } \\
\text { heritage }\end{array}$ & $\begin{array}{l}\text { Number of } \\
\text { replies }\end{array}$ & $\%$ \\
\hline $\begin{array}{l}\text { Pannonian salt } \\
\text { lakes }\end{array}$ & 350 & 59 & $\begin{array}{l}\text { Ethno courtyard } \\
\text { Lancaster }\end{array}$ & 250 & 42 \\
\hline healing springs & 100 & 16 & $\begin{array}{l}\text { Kula Huseinbega } \\
\text { Gradaščevića }\end{array}$ & 150 & 25 \\
\hline $\begin{array}{l}\text { Protected Landscape } \\
\text { Konjuh }\end{array}$ & 70 & 12 & $\begin{array}{l}\text { Archaeological Park in } \\
\text { Tuzla }\end{array}$ & 120 & 20 \\
\hline artificial reservoirs & 50 & 8 & $\begin{array}{l}\text { The medieval fortress } \\
\text { Srebrenik }\end{array}$ & 50 & 8 \\
\hline $\begin{array}{l}\text { Hunting grounds } \\
\text { Konjuh }\end{array}$ & 30 & 5 & Religious Buildings & 30 & 5 \\
\hline total respondents & 600 & & Total respondents & 600 & \\
\hline
\end{tabular}


Areas of the Tuzla Canton that are worth from the aspect of tourism are rated by respondents with an average score of 3,3 that indicates that they are wellknown with the conditions in this area. The analysis of the current situation in the Tuzla Canton has shown that most visitors consider that there is a favourable environment for the development of tourism, but there is a lack of accommodation capacities, and there is a poor road infrastructure.

\section{DEVELOPMENT POSSIBILITIES OF TOURISM IN THE TUZLA CANTON}

Through the research of the Tuzla Canton, there were analyzed available tourist values and their use in the development of tourism. There was used SWOT analysis as a basis for determining the comparative advantages in the tourism development of Tuzla Canton. The goal of this analysis is to identify the internal and external factors that influence the development of tourism. Based on the SWOT analysis, there were determined the priorities, measures, development vision and projects that will contribute to the development of tourism in the Tuzla Canton.

Based on the indicators, it can be concluded that the Tuzla Canton has more internal advantages than internal weaknesses, which enables the realization of comparative into competitive advantages or external threats into development opportunities. Internal weaknesses can be relatively rectified, it is primarily the lack of professional staff for project management and the development of tourist destinations. The tourist offer of Tuzla Canton is not on the satisfactory level, therefore, for the development of tourist industry, guidelines are necessary for improving the quality of services and accommodation. On the basis of these indicators, we can conclude that there is a significant constraint for tourism development, as evidenced by the fact that the tourism and transport infrastructure is under-developed.

The existing accommodation capacities are not sufficient for the reception of larger groups of visitors.

The development of tourism in the Tuzla Canton should be based on the principles of sustainable development as the only possible long-term competitive development option for this area, which includes a balanced development of the infrastructure, economy and culture, but with as little damage to the environment as possible. The basic principles of tourism require the creation of a quality tourism product, improvement of environmental quality, and the development of entrepreneurship in the tourism function. In this way, it can ensure competition in the tourism market.

Comparing the impacts of the factors through SWOT matrix, there were determined key and strategic guidelines and focusing is done on the basic aspects that may be carriers of the tourism development of the Tuzla Canton. 
Tab. 7. SWOT analysis of the resource base in Tuzla Canton

\begin{tabular}{|c|c|}
\hline $\begin{array}{l}\text { S Internal - power } \\
\text { (opportunities) }\end{array}$ & $\begin{array}{l}\text { W internal weaknesses } \\
\text { (problems) }\end{array}$ \\
\hline $\begin{array}{l}\text { - } \text { Favorable geographical position } \\
\text { - } \text { rivers Spreča, Drinjaca and } \\
\text { Oskova } \\
\text { - } \text { lake: Lukavac, Hazan, Vidar and } \\
\text { Snježnica } \\
\text { - Pannonian salt lakes } \\
\text { - healing springs in Gradacac, } \\
\text { - Gracanica, Tuzla and Srebrenik } \\
\text { Protected landscape nature } \\
\text { - } \text { Konjuh } \\
\text { - } \quad \text { touritural and historical heritage } \\
\text { - } \quad \text { hospitality }\end{array}$ & 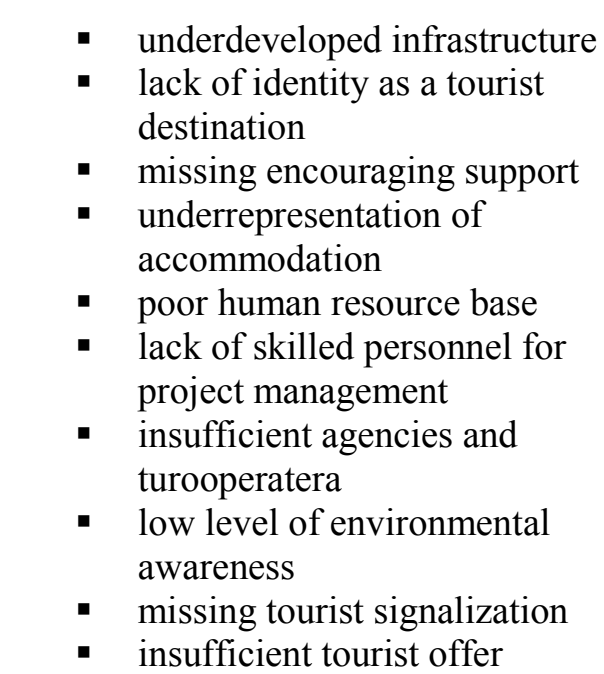 \\
\hline $\begin{array}{l}\text { O External - opportunities } \\
\text { (opportunities) }\end{array}$ & $\begin{array}{l}\text { T External threats } \\
\text { (uncertainty) }\end{array}$ \\
\hline $\begin{array}{l}\text { - the possibilities for the } \\
\text { development of health, excursions, } \\
\text { - } \text { rural tourism } \\
\text { - demand services in health tourism } \\
\text { - connecting tourist destinations } \\
\text { - development of complementary } \\
\text { - } \text { activities } \\
\text { - } \text { petter tourism promiding quality services } \\
\text { - } \text { employment of workers of tourism } \\
\text { - } \text { profession } \\
\text { - deaising living standards } \\
\text { - } \text { access to European funds }\end{array}$ & 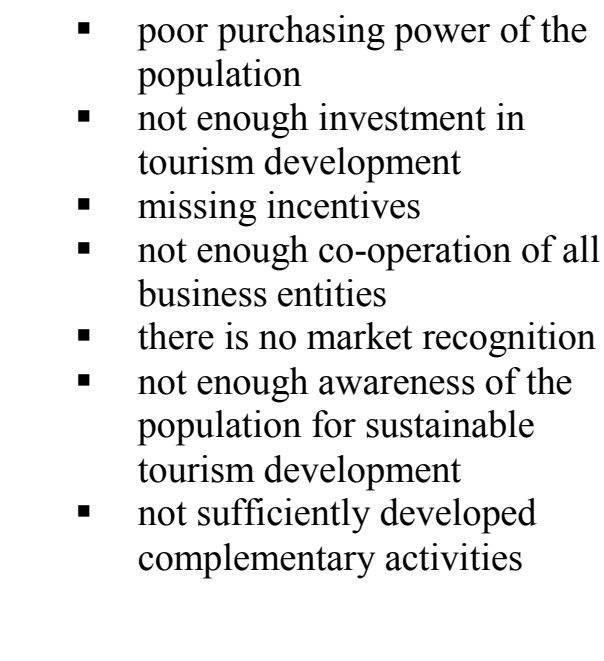 \\
\hline
\end{tabular}

\section{STRATEGIC DIRECTION AND MANAGEMENT OF TOURISM RESOURCES OF THE TUZLA CANTON}

Tourism is an activity for whose development, in terms of organization, a huge responsibility has the environment, from the lowest to the highest levels of management and authorities. Looking at the overall results achieved in the field of promotion of tourism in the municipalities of the Tuzla Canton, it is evident that in addition to protection of 
space, there was not sufficiently invested in the design of tourism facilities which would also contribute most to the development of tourism in this region. Investment in tourism facilities, infrastructure construction, renovation and expansion of capacities would lead to the enhancement of total turnover, primarily through collection of payment for useage of the built contents and revenue realized by catering as a supporting economic activity, and which forms an integral part of the overall tourism offer.

A chance for the development of tourism is based on the natural, cultural and historical heritage, which includes the conversion of existing comparative advantages, such as people, knowledge, natural resources and cultural and historical heritage, to the competitive advantage through clerical and creative services. Integrated systematic management in the future must have an important factor in the successful development of all types of business, and creation of their own cultural development as part of the system, ie. general culture of behavior of the organization that deals with tourism, as well as the organizational culture at the level of each segment of such organization.

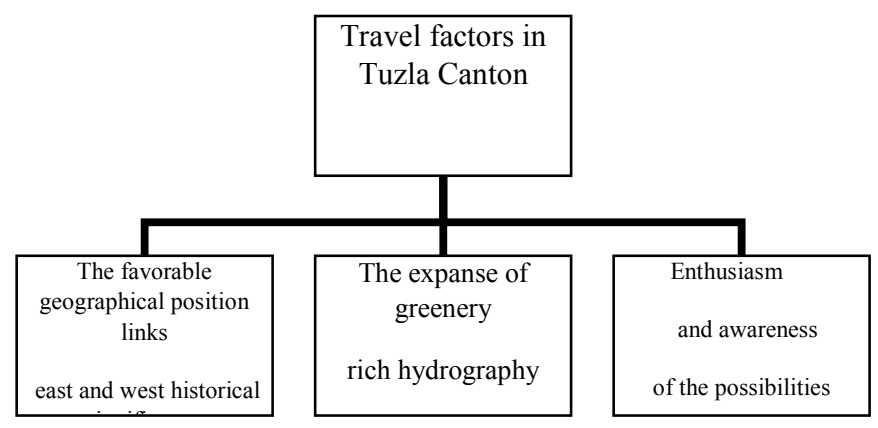

Fig 3. Travel factors in Tuzla Canton

After defining a developmental state, a logical sequence of activities is to find an effective and efficient organizational mechanism for successfully implementing the projected development goals as well as the realization of the same which would require the following: human resources management based on the principles of modern knowledge in municipality local communities, the development of studies or master plans in all municipalities except Srebrenik and Banovići, networking of all tourism service centers in the Tuzla Canton, connecting to one information center for booking and the reception of visitors.

Activation of alternative accommodations in motels, religious facilities (houses), family houses for pilgrims, scientists, organization of courses, exploring the culinary trends etc, the analysis of farm households owning an attractive location and tourist infrastructure, setting tourist signs on the roads with the appropriate welcome signs and direction signs to the tourist sights, production and sale of souvenirs, running the old crafts and activation of household cottage industry in Kladanj, Banovići, Tuzla, Sapna and Teočak, activation of picnic and camping terrains in suburban or rural environment for rest, entertainment and recreation. (Ilinčica and Kiseljak-Tuzla, Lipici-Srebrenik, Svatovac-Lukavac, TopliceŽivinice, Muška voda-Kladanj, Zlaća-Banovići). Successful business must be based on the continuous improvement of service quality. This can be achieved by mutual cooperation of all businesses and employees in the tourism industry.

In the concept of development, there should create a contact, identify partners, create a strategy for development, analyze the situation, offer the range of services, check the 
impact on the environment, take the initiative of government and analyze the results. Guidelines on improving the quality of services and accommodation should be conducted. Development of tourism should be managed from the canton level, working on joint cooperation of all stakeholders in order to build a tourist destination. Atractive and valuable areas should be adapted to standards, using experience with elements of hospitality, which provides the possibility of extended stay of visitors in tourist facilities. In the tourist orientation of areas, education of the local population is necessary in order to develop the tourist industry which is the foundation of the future survival on the tourism market. For the environmentally conscious tourists, development of mentioned types of tourism is very attractive because they are focused on nature, in addition to that the tourist offer should include the rich cultural heritage. Available unique resources require more forceful action on the management and direction of investments towards less developed tourist area, valorization of resources is a possibility for the expansion of tourism market, therefore we need a new quality in tourism development of the area. Economic development in the area of Tuzla Canton should be focused on a number of aspects of tourism. In this respect, in the forthcoming long term it is necessary to work towards the development of health and recreation, rural, cultural, religious and transit tourism. Integrated system management in the future must have an important factor of successful development of all types of business as well as creating their own culture development as a part of the system, ie. general culture of organizational behavior dealing with tourism. Natural sights and rarities, valuable forest systems, hydrological and geomorphological monuments, thermal and mineral spa give the character of authenticity, representa tiveness, diversity, integrity and landscape spatial values have scientific, cultural and historical, social and economic function and ecological significance. Natural conditions are suitable for the organization of summer and winter recreation in the mountain regions.

Numerous cultural monuments are the basis for the development of cultural tourism, as well as cultural manifestations. To achieve a higher income from services rendered, the tourist offer should include traditional Bosnian cuisine that has domestic dishes under the bell, homemade plum brandy, cheese, smoked meat, pies, cakes, a variety of drinks made from herbs. In addition to this, specialized, coffee, milk, fast food, seafood and vegetarian restaurants are necessary for modern catering offer. Based on the presented results, the general economic effects of tourism and catering economy in the canton are modest. Based on the total indicators and high lag in economic development, it is clear that the tourism sector do not provide anywhere near effects that are realistically possible. Assessment of the state of tourism in the Tuzla Canton highlighted the key features of the potential, advantages and disadvantages from the viewpoint of possible development. Internal power: high-preserved natural resources, cultural and historical heritage and hospitality should be converted into competitive advantages. Cooperation of all businesses and employees in the tourism industry can ensure that visitors receive quality service for which he spent his money. 


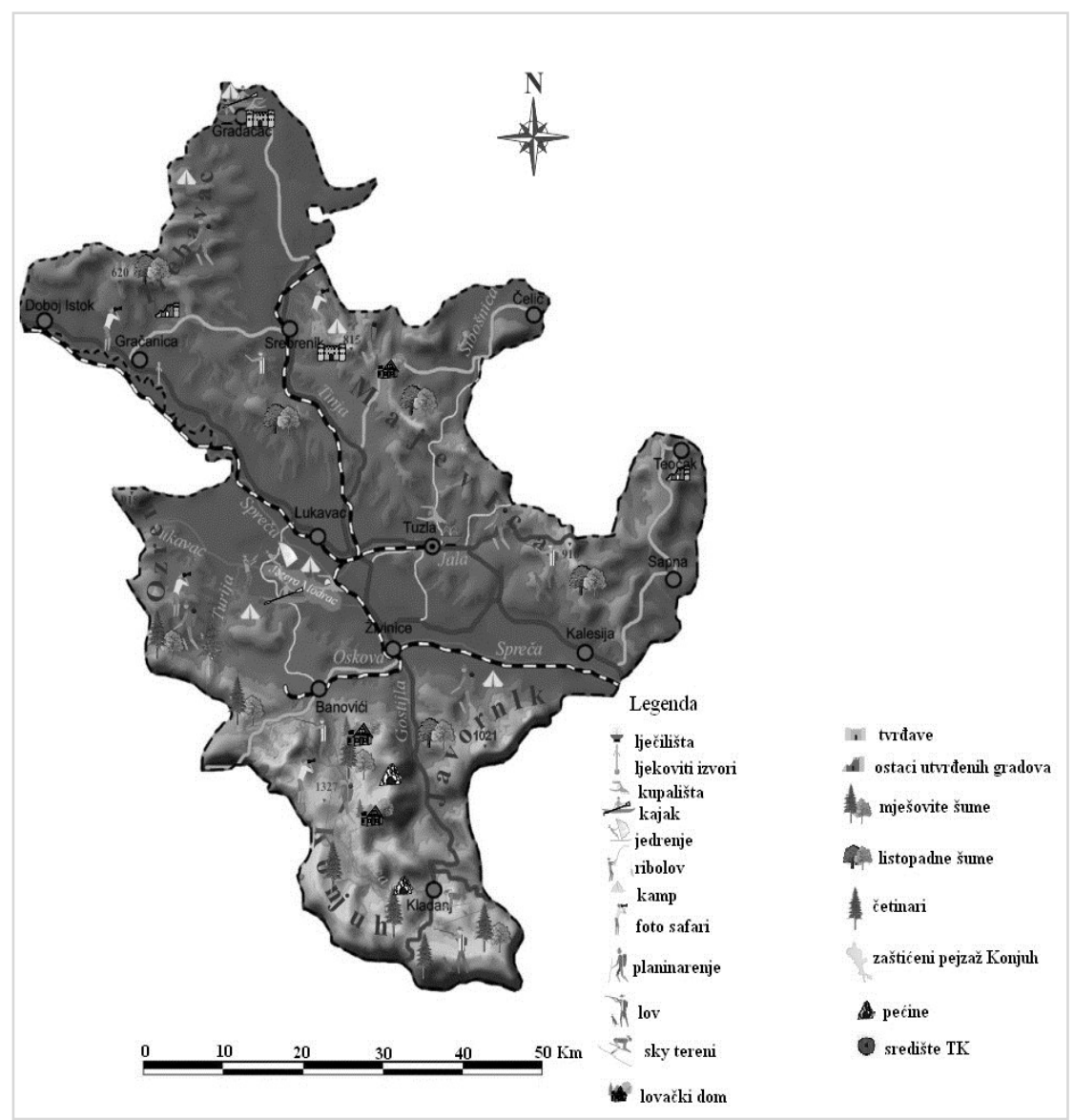

Fig 4. Tourist map of the Tuzla Canton

(the map done by the author)

\section{CONCLUSION}

Tourism can contribute to economic development of the area, improve the quality and standard of life and enable the creation of new jobs, reduce the number of unemployed only if it is approached with, a plan, monitoring the current situation and taking into account the needs of the market. The study of tourism market as a factor of economic development in the Tuzla Canton may allow making important marketing decisions based on accurate and verified information, research data, to improve tourism in all its segments, and which are the economic effects of it. The development of tourism in the Tuzla Canton should be positioned at finding quality content of tourist destinations to identify, valorize and turn into a competitive advantage through the development of specific types of tourism. Cultural and historical heritage, natural beauty, multiculturalism and tradition are the backbone of power on which to base strategic directions of development of the tourism industry of the Tuzla Canton. Existing tourism facilities favored certain communities as tourist destinations, only with a high-quality and efficient cooperation of all segments of importance to tourism development can be achieved competitive advantage. 


\section{REFERENCES}

1. The Constitution of Bosnia and Herzegovina, the Dayton Agreement, Annex 4 1995: article.1.3. p.74.

2. Photomonography Tuzla, 2007, Copyright, Bosnia ars, Tuzla, p.25

3. Archive of the Panonika enterprise, 2013, Tuzla

4. Spatial plan for areas of TK (2005-2015), Official Gazette TK 06/09 (2008), Tuzla

5. The Agency for Statistics of Bosnia and Herzegovina (2013): The only relevant data of the Population and Housing in $\mathrm{BiH}$ 2013. officially published results of the Agency for Statistics of Bosnia and Herzegovina and Entity Statistics Bureau.

6. Tourist Board of Tuzla Canton, 2014, Tuzla

7. The Government of Tuzla Canton, The Ministry of Trade, Tourism and Transport of Tuzla Canton, 2014, Tuzla 